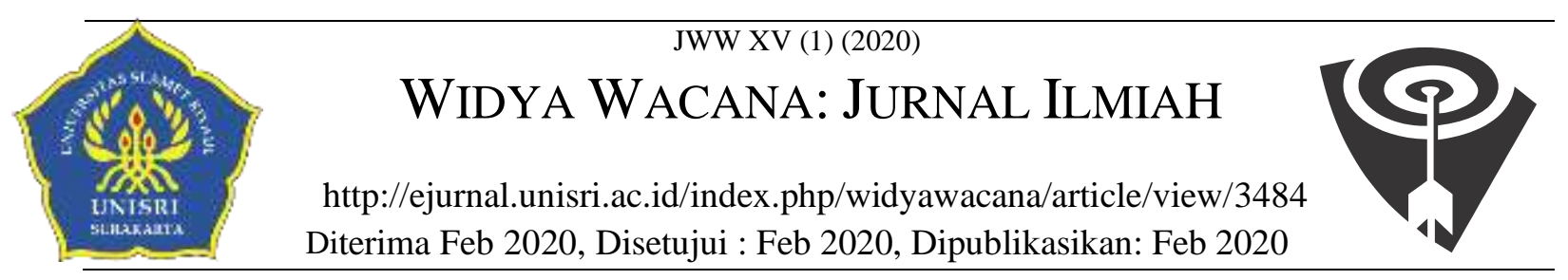

\title{
PEMANFAATAN GOOGLE CLASSROOM DALAM MATAKULIAH MENGGUNAKAN MEDIA VIDEO SCREENCAST O-MATIC
}

\author{
Buaddin Hasan \\ Program Studi Pendidikan Matematika STKIP PGRI Bangkalan \\ Email: buaddinhasan@stikppgri-bkl.ac.id
}

\begin{abstract}
ABSTRAK
Perkembangan teknologi sangat pesat di berbagai bidang tidak terkecuali bidang pendidikan. Perkembangan ini bisa saja menghambat pembelajaran jika tidak diikuti dengan sikap positif dari pengajar ataupun pelajar. Perkembangan teknologi sering kali tidak dimanfaatkan dengan baik dalam proses pembelajaran sehingga dapat menjadikan siswa merasa kurang betah untuk belajar di kelas. Tujuan penelitian ini untuk menguji keefektifan pembelajaran matematika dengan memanfaatkan google classroom menggunakan media video screencast o-matic. Jenis penelitian ini adalah kuatitatif dengan pendekatan quasi eksperiment. Sampel dalam penelitian ini adalah mahasiswa semseter V prodi pendidikan matematika yang dipilih dengan metode random sampling. Teknik analisis data menggunakan uji normalitas, uji homogenitas, serta uji hipotesis. Uji normalitas dilakukan dengan menggunakan chi kuadrat, uji homogenitas menggunakan uji-F. Sedangkan uji hipotesis menggunakan uji t-test. Setelah proses analisis data dilakukan, maka peneliti menyimpulkan efektif atau tidaknya pembelajaran dengan memanfaatkan google classroom menggunakan media video screencast o-matic. Hasil penelitian menyimpulkan bahwa pemanfaatan kelas online google classroom menggunakan media video screencast o-matic pada matakuliah pengembangan media berbasis komputer sangat efektif.
\end{abstract}

\section{Kata Kunci: Google Classroom, Media, Screencast O-Matic}

\begin{abstract}
The development of technology is very rapid in various fields including education. This development can hamper learning if it is not followed by a positive attitude from the instructor or student. The development of technology is often not utilized properly in the learning process so that it can make students feel less comfortable to learn in class. The purpose of this study is to test the effectiveness of mathematics learning by utilizing google classroom using o-matic video screencast media. This type of research is quantitative with a quasi experimental approach. The sample in this study were semseter $V$ students of mathematics education study programs selected by the random sampling method. Data analysis techniques using the normality test, homogeneity test, and hypothesis testing. Normality test is done using chi squared, homogeneity test using the F-test. While testing the hypothesis using the t-test. After the data analysis process is carried out, the researcher concludes whether or not learning is effective by utilizing Google classroom using o-matic video screencast media. The results of the study concluded that the use of online classroom google classroom using video screencast o-matic media in the course of developing computer-based media is very effective.
\end{abstract}

Keywords: Google classroom, media, screencast o-matic

\section{PENDAHULUAN}

Perkembangan teknologi jaringan internet telah mengubah paradigma dalam mendapatkan informasi dan berkomunikasi, yang tidak lagi dibatasi oleh dimensi ruang dan waktu (Adri, 2007). Melalui keberadaan internet mereka bisa mendapatkan informasi yang dibutuhkan dimanapun dan kapanpun waktu yang diinginkan.

Salah satu bidang yang tersentuh dampak perkembangan teknologi ini adalah dunia pendidikan. Sebagai sebuah sumber informasi yang hampir tidak terbatas, maka jaringan internet memenuhi kapasitas dijadikan sebagai salah satu sumber pembelajaran dalam dunia pendidikan. 
Bahkan beberapa perguruan tinggi ternama, mencanangkan lahirnya sistem pembelajaran yang berbasiskan teknologi jaringan ini, seperti lahirnya konsep tentang distance learning, web-based education, dan $e$ learning.

Melihat perkembangan fenomena ini, maka dapat dipastikan dunia pendidikan kita akan tertinggal jika tidak bisa memanfaatkan teknologi internet. Walaupun belum akan melaksanakan pengajaran maupun pendidikan berbasiskan internet, setidaknya pendidikan mampu dan menganjurkan pemanfaatan resources yang ada di internet sebagai salah satu sumber pembelajaran maupun bahan pengajaran.

$$
\text { E-learning sebagai model }
$$

pembelajaran baru dalam pendidikan memberikan peran dan fungsi yang besar bagi dunia pendidikan yang selama ini dibebankan dengan banyaknya kekurngan dan kelemahan pendidikan konvensional diantaranya adalah keterbatasan ruang dan waktu dalam proses pendidikan konvensional. Teknologi informasi yang mempunyai standar platfom internet yang bisa menjadi solusi permasalahan tersebut karena sifat internet yang memungkinkan segala sesuatu saling terhubung belum lagi karakter internet yang murah, sederhana dan terbuka mengakibatkan internet bisa digunakan oleh siapa saja, dimana saja, kapan saja dan bebas digunakan (Kholifah, 2016)

Salah satu pembelajaran yang menggunakan jaringan internet (e-learning) adalah google classroom, pemilihan google classrom dalam penelitian ini karena aplikasi google app for education sebelumnya yaitu hanya google docs dan goole form. Google classroom adalah fitur terbaru dari google app for education yang dapat dimanfaatkan oleh guru dan dosen, siswa dan mahasiswa dalam proses pembelajaran (Hakim, 2016). Kunggulan google classroom adanya pembuatan grup kelas dan sub grup kelas, pembuatan assigment, dan pembuatan quiz, penilaian, materi dan tugas tersimpan secara otomatis di google drive. dosen dapat memberikan berita atau tes secara online, selain itu google calasroom menyediakan ruang diskusi dengan mahsiswa. Penerapan google classroom sebagai media dapat meningkatkan aktivitas belajar siswa (Mustaniroh, 2015)

Perpaduan pembelajran e-learning dengan media yang menarik diharapkan dapat memberikan motivasi belajar kepada mahasiswa dalam memahami konsep secara mandiri. Media pembelajaran yang dapat menjelaskan konsep manteri secara jelas dan mudah dibuatnya adalah komik digital video screencast o-matic. Pembelajaran menggunakan media screecast o-matic dapat meningkatakan kemampuan guru dalam beriteraksi (Priowirjanto, 2013). The online class of student will have increased succes because of the addition of screencast (Peterson, 2007).

Screencast-o-matic ini berupa software yang dapat merekam semua media pembelajaran e-learning menjadi sebuah video tutorial. (Thomson, 2014). Pembelajaran menggunakan media video screencast o-matic meningkatkan minat belajar siswa (Suryanto, 2014). power point based screencast o-matic videos can increase interest in learning, as well as the easy absorption of the material so that it can improve student learning outcomes teaching elementary mathematics (Hasan, 2017).

Penelitian ini mengkaji tentang efektifitas pembelajaran online dengan google classroom menggunakan media video screencat o-matic. Penelitian ini dapat dijadikan sebagai metode pembelajaran yang baru dengan memanfaatkan internet sehingga proses pembelajaran tidak terbatas oleh ruang dan waktu. Keunggulan dari penelitian ini dalam proses pembelajaran online peneliti menggunakan media video pembelajaran berbasis screenscat o-matic untuk menjelaskan materi secara online. Video tersebut dapat dilihat berulang kali oleh mahasiswa dimanapun dan kapanpun menggunakan android yang dimiliki.

\section{KAJIAN PUSTAKA}

E-learning adalah pengajaran dan pembelajaran yang didukung dan dikembangkan melalui teknologi dan media digital, dan juga konsep distance learning atau belajar jarak jauh (Hakim, 2016). Di masa sekarang ini e-learning menjadi suatu 
keharusan bagi perguruan tinggi untuk membantu dalam aktivitas belajar dan mengajar.

Islamiyah (2016) menyatakan Elearning merupakan sebuah bentuk teknologi informasi yang diterapkan di bidang pendidikan dalam bentuk dunia maya. Istilah e-learning lebih tepat ditujukan sebagai usaha untuk membuat sebuah tranformasi proses pembelajaran yang ada di sekolah atau perguruan tinggi ke dalam bentuk digital yang dijembatani oleh teknologi internet. Hakim (2016) menyatakan beberapa manfaat e-learning yang dilihat dari 2 sudut pandang yaitu sudut pandang siswa dan sudut pandang pengajar. Diantaranya;

Dari sudut pandang pelajar, e-learning memungkinkan fleksibilitas belajar yang tinggi, juga memungkinkan siswa berkomunikasi dengan pengajar setiap saat, misalnya dengan memanfaatkan fasilitas chatting atau email. Dari sudut pandang pengajar, penggunaan sistem e-learning memungkinkan pengajar untuk lebih mudah melakukan pembaruan materi maupun model pengajaran sesuai dengan tuntutan perkembangan keilmuan, juga dapat dengan efisien mengontrol kegiatan belajar siswanya. Berdasarkan pendapat para ahli di atas disimpulkan bahwa e-Learning pada penelitian ini adalah suatu bentuk pembelajaran berbasis web yang bisa di akses dari internet di jaringan lokal atau internet.

Google Classroom adalah sebuah aplikasi yang memungkinkan terciptanya ruang kelas di dunia maya. Google classroom bisa menjadi sarana distribusi tugas, submit tugas bahkan menilai tugastugas yang dikumpulkan. Google classroom bisa didapatkan secara gratis dengan terlebih dahulu mendaftarkan diri pada akun Google Application for Education (Dhia, 2017). Google Classroom dirancang untuk membantu pengajar membuat dan mengumpulkan tugas tanpa kertas, termasuk fituryang menghemat waktu seperti kemampuan untuk membuat salinan Google Dokumen secara otomatis bagi setiap siswa. Google classroom juga dapat membuat folder Drive untuk setiap tugas dan setiap siswa, agar semuanya tetap teratur. Pengajar dapat melihat dengan cepat siapa saja yang belum menyelesaikan tugas, serta memberikan masukan dan nilai langsung di Google Classroom.

Menurut Pradana (2017) Google Classroom merupakan sebuah produk bagian dari Google For Education yang menurut penulis sangat istimewa, karena produk yang satu isi memiliki banyak fasilitas didalamnya seperti memberi pengumuman atau tugas, mengumpulkan tugas dan melihat siapa saja yang sudah mengumpulkan tugas. Google For Education itupun sendiri merupakan sebuah layanan yang terkenal didunia yaitu Google. Seperti namanya Google For education diciptakan untuk memenuhi kebutuhan penggunaannya dalam bidang pendidikan. Seperti yang dituliskan pada situs resminya, Google For Education memiliki beberapa Layanan yang sangat membantu dalam proses belajar mengajar di sekolah, seperti Google Classroom, Google Mail, google drive, google Calender, Google docs, Google Sheets, Google Slides, dan Google Sites.

Manfaat Google Classroom menurut Dhia (2017) Google Classroom ini sangat bermanfaat untuk pembelajaran secara online, dapat diperoleh secara gratis serta dapat digunakan untuk perangkat apa pun. Salah satu kecanggihan aplikasi ini adalah dapat digunakan secara bersama-sama dalam kelompok secara kolaboratif. Ada beberapa keuntungan yang kita dapatkan dari Google Classroom dalam pemanfaatannya sebagai Learning Management System (LMS). Hanya perlu beberapa menit untuk menyiapkan. Alur tugas yang sederhana dan tanpa kertas memungkinkan pengajar membuat, memeriksa dan menilai tugas dengan cepat, di satu tempat. Siswa dapat melihat semua tugasnya di laman tugas dan semua materi kelas secara otomatis disimpan ke dalam folder di Google Drive. Google Classroom memungkinkan pengajar untuk mengirim pengumuman dan memulai diskusi secara langsung. Siswa dapat berbagai sumber daya satusama lain atau memberikan jawaban atas pertanyaan di aliran. Seperti layanan Google apps for education lainnya, Google Classroom tidak mengandung iklan, tidak pernah menggunakan data siswa untuk 
iklan, dan gratis untuk sekolah. Meskipun masih memiliki Kelemahan seperti tidak adanya layanan eksternal seperti bank soal secara otomatis dan obrolan secara pribadi antar untuk mendapat umpan balik.

Media pembelajaran Screencast-OMatic merupakan media pembuatan video singkat yang dapat menjelaskan materi secara menarik dan siswa dapat menguasainya secara mandiri. Penggunaan Media Visual Screencast-O-Matic Sebagai Upaya Meningkatkan Hasil Belajar Siswa arena siswa dapat menguasainya secara mandiri dan dapat mempelajarinya pada waktu di luar jam sekolah (Wardani, 2015). Screencast-O-Matic dapat meningkatkan minat belajar, serta mudah dalam penyerapan materi sehingga dapat meningkatkan hasil belajar siswa. Dengan demikian, mahasiswa perlu diberdayakan dengan pemanfaatan media Screencast-O-Matic agar motivasi dan hasil belajar siswa dapat meningkat (Suryanto H. , 2014)

Screencast adalah teknik membuat video dengan cara merekan aktifitas di layar komputer. Cara ini sangat mudah dan dapat dimanfaatkan untuk membuat video pembelajaran. Ada beberapa software yang dapat digunakan untuk membuat screencast. Dalam buku ini kita akan membahas dua di antaranya. Yang pertama adalah Screencast$o$-matic, yang merupakan salah satu software untuk screencast yang dapat digunakan secara online maupun offline

Penggunaan media pembelajaran memberikan banyak manfaat bagi seorang guru dan siswanya. Salah satunya menurut Hasan, B. (2017, August 30). Media power point based screencast o-matic videos can increase interest in learning, as well as the easy absorption of the material so that it can improve student learning outcomes teaching elementary mathematics.

Sedangkan menurut Wijayanti, R., Hasan, B., \& Loganathan, R. K. (2018) pengguaan media comic video berbasis whiteboard animation layak untuk digunakan dalam proses pembelajaran matematika disekolah. Dan pembelajaran menggunakan media comic video berbasis whiteboard animation pada materi geometri bangun datar sangat efektif

\section{METODE}

Jenis penelitian ini adalah kuatitatif dengan pendekatan eksperimental dengan menggunakan sampel mahasiswa semester $\mathrm{V}$ prodi pendidikan matematika pada matakuliah media pembelajaran berbasis komputer. Data dalam penelitian ini diperoleh dengan metode tes dan angket. metode tes dilakukan untuk memperoleh data hasil belajar yang kemudian digunakan sebagi data uji hipotesis. Sedangkan untuk memperoleh data respon mahasiswa terhadap pembelajaran e-learning google classroom berbasis android menggunakan media video komik digital screencast o-matic dilakukan dengan metode pemberian angket respon.

Setelah data penelitian terkumpul, maka akan dilakukan beberapa teknik analisis data yaitu uji normalitas, uji homogenitas, serta uji hipotesis. Uji normalitas akan dilakukan dengan menggunakan chi kuadrat. Uji ini dimaksudkan untuk mengetahui populasi yang dipilih pada penelitian ini berdistribusi normal atau tidak. Teknik analisis data yang kedua pada penelitian ini akan menggunakan uji homogenitas yang dilakukan dengan menggunakan uji-F. Uji ini dimaksudkan untuk mengetahui pakah varians data kedua kelompok yang diteliti mempunyai varians yang homogen atau tidak. Sedangkan uji terakhir yang digunakan adalah uji hipotesis dengan menggunakan bantuan uji t-test dengan rumus sebagai berikut:

$$
\begin{array}{cc}
t=\frac{\bar{x}_{1}-\bar{x}_{2}}{s \sqrt{\frac{1}{n_{1}}}+\sqrt{\frac{1}{n_{2}}}} & \text { dengan } \\
& s^{2}=\frac{\left(n_{1}-1\right) s_{1}^{2}+\left(n_{2}-1\right) s_{2}^{2}}{n_{1}+n_{2}-2}
\end{array}
$$

Setelah proses analisis data dilakukan, maka peneliti akan menyimpulkan efektif atau tidaknya pembelajaran e-learning google classroom menggunakan media video komik digital screencast o-matic.

\section{HASIL DAN PEMBAHASAN}

Pemanfaatan google classroom dengan menggunakan media screencast $o$ matic efektif digunakan kepada mahasiswa pada matakuliah pengembangan media berbasis komputer. 


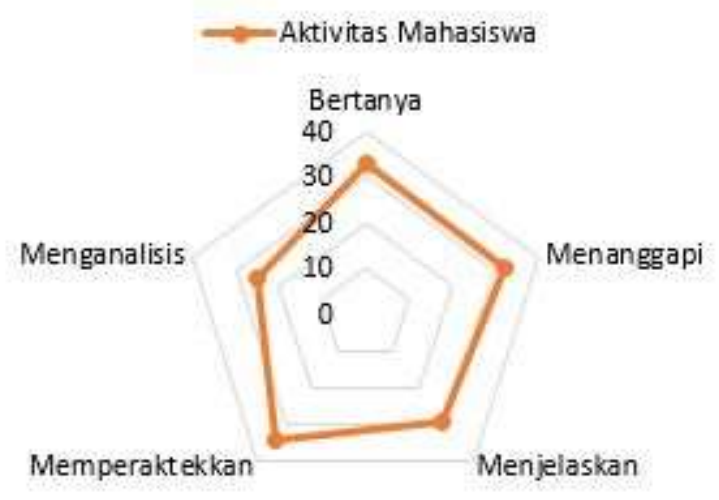

Gb 1. Aktivitas mahasiswa dalam pemanfaatan Google Classroom Menggunakan Media Video Screencast O-Matic

Hal ini digambarkan dengan jelas pada grafik bahwa jenis aktivitas yang dilakukan oleh mhasiswa secara keseluruhan termasuk aktivitas yang membuat siswa aktif dalam pembelajaran dan menunjukkan antusias mahasiswa dalam mengikuti matakuliah. Mahasiswa menyampaikan pertanyaan sebanyak 33 mahasiswa atau 91\% dari 36 sampel kelas ekperimen, mahasiswa mampu menanggapi pertanyaan sebanyak 32 atau $88 \%$ dari 36 sampel kelas eksperimen, mahasiswa mampu menjelaskan kembali isi materi sebanyak 29 orang atau $80 \%$ dari 36 sampel. Mahasiswa mampu mempraktekan tugas sebanyak 34 atau $94 \%$ adri 36 sampel. Sedangkan mahasiswa yang mampu menganalisi hasil tugas hanya $70 \%$ atau 25 mahasiswa dari 36 sampel.

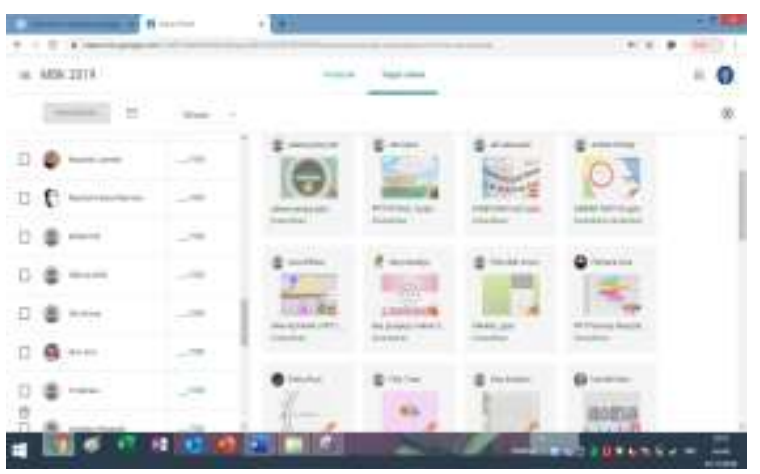

Gb 2. Bentuk Tugas Pada Kelas Online Google Classroom Menggunakan Media Screencast $O$-matic

Selain data aktivitas mahasiswa, data peneliti juga mendapatkan hasil belajar mahasiswa yang kemudian dianalisis. Untuk mendapatkan nilai $x_{t a b e l}^{2}$ menggunakan chi kuadrat tabel :

$x_{\text {tabel }}^{2}=x_{(1-\alpha)(d k)}^{2}$

$x_{(1-0,005)(5)}^{2}=x_{(0,95)(5)}^{2}=11,1$.

dari hasil perhitungan diketahui bahwa $x_{\text {hitung }}^{2}$ sebesar 9,47 dan $x_{\text {tabal }}^{2}$ sebesar 11,1. Berdasarkan data tersebut menunjukkan bahwa $x_{\text {hitung }}^{2}<x_{\text {tabel }}^{2}$. Hal ini dapat disimpulkan bahwa distribusi data nilai post test pada kelas eksperimen berdistribusi normal. Untuk uji normalitas pada kelas kontrol diperoleh bahwa pada kelas kontrol $x_{\text {hitung }}^{2}<x_{\text {tabel }}^{2}$ sama seperti halnya dengan kelas eksperimen. Artinya, kelas kontrol juga berdistribusi normal.

Setelah dibuktikan bahwa kedua kelas baik kelas eksperimen maupun kelas kontrol sama-sama berdistribusi normal, maka langkah selanjutnya dilakukan uji homogenitas dengan menggunakan rumus uji-F yaitu :

varians $=\sum x_{1}-\frac{\frac{\left(\sum x_{1}\right)^{2}}{N}}{N-1}$

dan

uji statistik $=F=\frac{\text { varians terbesar }}{\text { varians terendah }}$

Berdasarkan hasil perhitungan diperoleh hasil bahwa $F_{\text {hitung }}=1,05$ dan $F_{\text {tabal }}=1,80$ sehingga dapat disimpulkan bahwa $F_{\text {hitung }}<F_{\text {tabel }}$. Artinya kedua kelas yang digunakan adalah homogen.

Uji terakhir yang dilakukan dalam penelitian ini adalah uji hipotesis. Untuk menguji hipotesis dalam penelitian ini digunakan uji-T. Berikut ini adalah hasil analisis dari uji-T

$S_{\text {gabungan }}=\sqrt{\frac{\left(n_{1}-1\right) s_{1}{ }^{2}+\left(n_{2}-1\right) s_{2}{ }^{2}}{n_{1}+n_{2}-2}}$

$=\sqrt{\frac{(36-1) 94,38+(34-1) 89,33}{36+34-2}}=\sqrt{\frac{6251,19}{68}}=\sqrt{91,929}=9,58$

Setelah simpangan baku diperoleh, kemudian menggunakan analisis uji-t dengan perhitungan sebagai berikut 
$t=\frac{\overline{x_{1}}-\overline{x_{2}}}{s \sqrt{\frac{1}{n_{1}}+\frac{1}{n_{2}}}}=\frac{80,9-61,8}{9,58 \sqrt{\frac{1}{36}+\frac{1}{34}}}=\frac{19,1}{2,335}=8,12$

Karena dari hasil perhitungan diperoleh $t_{\text {hitung }}=8,12$ dan $t_{\text {tabel }}=1,99834$, maka $H_{1}$ diterima dan $H_{0}$ ditolak. Artinya bahwa pemanfaatan kelas online google classroom menggunakan media video screencast omatic pada matakuliah pengembangan media berbasis komputer dikatakan efektif. Hal ini senada dengan penelitian Hakim, A. B. (2016) yang menyatakan bahawa pengguanaan E-Learning Moodle, Google Classroom dan Edmodo efektif diterapkan dalam pembelajaran online.

\section{KESIMPULAN DAN SARAN}

Berdasarkan hasil analisis data yang dilakukan oleh peneliti, maka dapat disimpulkan bahwa media pemanfaatan google classroom menggunakan media screencast o-matic pada matakuliah pengembangan media berbasis komputer efektif, hal ini dilihat dari beberpa aspek, antara lain:

1. Terjadi interaksi anar mahasiswa dalam berdiskusi secara online pada kelas google classroom, mahasiswa mampu mengikuti matakuliah dengan menyimak video pembelajaran berbasis screencast $o$ matic.

2. Hasil eksperimen yaitu kelas yang memanfaatkan google classroom menggunakan media video screencast omatic lebih baik dibandingkan dengan kelas kontrol yang menggunakan sistem direct learning menggunakan media power point.

Dari hasil penelitian, peneliti menyarankan ketika menggunakan kelas online berbasis google classroom perlu adanya media interaktif yang digunakan untuk menyampaikan materi. Lebih baik jika medianya berupa video pembelajaran.

\section{DAFTAR PUSTAKA}

Adri, M. (2007). Pemanfaatan Internet sebagai Sumber Pembelajaran Semiloka Pengembangan Model
Pembelajaran Berbasis Teknologi Informasi . FT UNP Padang.

Hakim, A. B. (2016). Efektifitas Penggunaan E-Learning Moodle, Google Classroom Dan Edmodo. ISTATEMENT, 2(1).

Hasan, B. (2017). Teaching Elementary Mathematics using Power Point Based Screencast O-Matic Videos. ISMEI 4. Yogyakarta: Qitep In Math.

Kholifah, S. (2016). The Development of Learning Video Media Based on Swishmax and Screencast O-Matic Software through Contextual Approach. Dinamika Pendidikan, 11(1), 50-55.

Kurniawan, H. (2015). Efektifitas Pembelajaran Problem Solving Dan Investigasi Terhadap. Surya Edukasi.

Munadi, Y. (2018). Media Pembelajaran. Jakarta: Gaung Persada (GP) Press.

Mustaniroh, S. A. (2015). Penerapan Google Classroom Sebagi Media Pembelajaran Pada Pelajaran Kimia di SMK Negeri 2 Temanggung. Skripsi.

Peterson, E. (2007). Incorporating Screencast in Online Teahing. International Review of Research in Open and Distance Learning. USA: Montana State University.

Priowirjanto, Y. P. (2013). Materi simulasi digital. Southeast Asian Ministers of Education Organization Regional Open Learning Centre.

Suleiman, A. H. (2016). Media Audio-Visual Untuk Pengajaran. Penerangan.

Suryanto, H. (2014). Pengembangan Multimedia E-Learning Berbasis Screencast-O-Matic Dalam Pembelajaran Matematika. Jurnal Ilmu Sosial dan Humaniora ISSN: 2407-7550,, Vol. 1, No. 1.

Wijayanti, R., Hasan, B., \& Loganathan, R. K. (2018). Media comic math berbasis whiteboard annimation dalam pelajaran matematika. Jurnal Riset Pendidikan Matematika, 5(1), 53-63.

Thomson, A. B. (2014). Teachers flipping out'beyond the online lecture: Maximising the educational potential 
of video. Journal of Learning Design, 7(3), 67-78.

Zain, S. B. (2010). Strategi Belajar Mengajar. Jakarta : Rineka Cipta. 